\title{
Arabicization: Morphological or Syntactic Phenomenon?
}

\author{
Majduldin Sayed Nugdalla \\ Department of European Languages, Faculty of Arts and Humanities \\ King Abdulaziz University, Jeddah, Saudi Arabia. \\ Department of English \& Translation, Faculty of Science \& Arts \\ Khulais Branch, University of Jeddah, Jeddah, Saudi Arabia. \\ Mahgoub Dafalla Ahmed \\ Department of European Languages, Faculty of Arts and Humanities \\ King Abdulaziz University, Jeddah, Saudi Arabia. \\ Department of English \& Translation, Faculty of Science \& Arts \\ Khulais Branch, University of Jeddah, Jeddah, Saudi Arabia.
}

\begin{abstract}
The current study explores the nature of Arabicization from the viewpoint of whether it is morphological, syntactic or morpho-syntactic phenomenon. It describes the lexicology of Arabicized words: the structure of words, meaning components and their relations to each other. The study attempts to approach the etymological methods of entry of lexical items into Arabic as with respect to loan words, derivation and generation and their roles in word-formation processes. Additionally, the study tries to investigate whether derivation processes can work with the Arabicized words. It seeks to establish the difference between the original Arabic words and the Arabicized words on the basis of which concept of Arabicization formerly and presently shall be approached. It ultimately seeks to pinpoint the fact pertinent to the efforts exercised to design a linguistic methodology to handle the Arabicized words along the lines of original existing Arabic terms. This is carried out with the aim of adjusting poly-term phenomenon chiefly observed in Arabic in having a number of equivalents for a single concept as corresponding to that of the source language.
\end{abstract}

Key words: Al-ta ${ }^{3}$ rīb, Arabicization, arabicized words, Arabic language

\section{INTRODUCTION}

Arabic language is considered as one of the most predominantly influential languages of the world. It is founded on a rich history and an exuberant heritage in the field of literature, theology and science. The location of the Arabian Peninsula in the crossroads of the great empires and the wealthy cultures of Persia, Greece, and Rome inspires the Arabic language to interact wittingly or unwittingly with the languages of these nations. In addition, factors like invasions, migrations, and trade have disclosed Arabic language to these cultures. These cultures have greatly influenced Arabic and exposed its words to various processes of formation. One of these processes is Arabicization. The current study describes the phonological, morphological and syntactical adjustment that occurred to foreign words when they were arabicized. Throughout this paper, Arabic is transcribed into Roman script representation, through a certain typographic convention. The example of the Persian word < dashit, "the desert", which is arabicized into > dist indicated by the inequality signs: greater than $(<)$ to indicate the origin word and less than $(>)$ to indicate the arabicized word, shows the graphemic transliteration (IJMES Transliteration System) which is used in this study. 


\section{Some Basic Facts about Arabic Language}

Morphologically, Arabic language is considered as the most complicated of all languages. Like many other languages, Arabic words are formed from concatenating morphemes using a certain pattern. Hundreds of words can be formed using one root, a few patterns, and a few affixes. Owing to certain morphological patterns including the omission of vowels and the similarity of letters affixed to the stem or the root letters of the language, Arabic throws up a high degree of ambiguity. In many other languages like English for example, the root (base, stem, core) is the morpheme that provides the basic meaning of a word. It is that part of the word, which remains after the removal of affixes. In Arabic, however, the root is not necessarily to be the origin of the word i.e. the original form of the word before any transformation process (Al-Atram, 1990). According to Al-Atram (1990) Arabic prefixes are sets of letters and articles attached to the beginning of the lexical word and written as part of it, while suffixes are sets of letters, articles or pronouns attached to the end of the word and written as part of it. Compared to English, Arabic has fewer affixes, but these affixes exhibit the feature of concatenating with each other in predefined linguistic rules. The removal of prefixes in English is usually counterproductive because it can reverse or otherwise alter the meaning or the grammatical function of the word, but in the Arabic language, the removal of prefixes is not adverse and does not usually give negative meanings of words.

\section{What is "Arabicization"?}

There are three views about Arabicization. The first view, which opposes Arabicization maintains that the overflow of foreign words will disturb the Arabic language and overwhelm it. The second view favors the indiscriminate use of foreign words in the original form, while the third view stands moderate insisting on foreign words being accepted only if there are no equivalents in Arabic. Contrary to the view maintains that Arabicization leads to overflow of foreign words, Arabicization would only lead to the consolidation of the Arabic society and ameliorate it by enhancing its personality and its capacity to think qualitatively.

Words borrowed into Arabic language are of two types: "Al-Mũrrab" "Arabicized" and "Addakhill" "loan". Arabicization is derived from the word "Arabic", the language spoken by Arabs. To 'arabicize' means to transfer, transcript or transcribe a non-Arabic script into Arabic. Arabicizing" a foreign word is the process of fitting it in to suit the rules of Arabic language. Arabic language stipulates two conditions while assimilating words from other languages. The first condition is that the word needs to be arabicized must not be a part of the original Arabic lexicon. Examples for this type are found in the new scientific inventions and discoveries such as the word "mobile". The second condition is that these new words have to merge with the morphological and phonological systems of the Arabic language.

Many linguists have tried to define Arabicization "Al-ta ${ }^{\circ} r \bar{i} b$ ". A common definition for Arabicization is the assimilation of foreign terminology through borrowing or translating. AlMŭrrab is used be the Arabs to explain certain meanings in other languages. Accordingly, Sebaweyeh (1983) defined "al-Mŭrrab" as words used by the Arabs for meanings that are not found in Arabic language. In the same vein, Al-Zubaidi $(1966: 8,226)$ and As-Sŭti (1906) in 'AlMizhir' agreed with Sebaweyeh, noting the arabicized word is the word used by the Arabs for meanings in other languages. In his book, 'Al-khasais', Ibn Jinni (1951: 358), who followed Sibawayeh, stated that any borrowed word agrees with the morphological pattern of Arabic language is treated as Arabic word. However, Al-Tha'albi (1038) in 'Fiqih Al-lŭqa' (p. 198,199) noted, when the Arabs derive from foreign words, they violate the morphological pattern of 
Arabic language. Al-Jawahri (1978) pointed out, for the foreign word to be arabicized, it has to be used and repeated by the Arabs in their daily speech. According to Al-Khafaji (1998) "Al$t a^{\circ} r \bar{i} b$ " "Arabicization" is transferring the foreign lexeme into Arabic language. The author of 'Al-Misbah Al-Munir', Alfayumi (1993: 2-4) defined the arabicized word as what entered the Arabic language from another language as an indefinite word and adjusted to cope with the Arabic morphological pattern. Recently, Saydi (1985) has defined Arabicization as follows:

"It refers to lexical expansion which involves the rendering or coinage of new words either from existing roots, or through translation of foreign terms, and the adoption of already existing words through borrowing from foreign words through borrowing from foreign languages or reviving and revitalization of older usage in the same language."

Ghoniem (1989: 37-80) pointed out three meanings for Arabicization 1) the use of loan words after have been adjusted to the morphological and phonological patterns of Arabic language, 2) direct translation from foreign languages into Arabic "calque", and 3) a constitutional process which refers to the efforts undertaken by the Arabic language academies as an attempt to urge Arabic to be used at individual, national and international levels as a language of thought and science, which is beyond the scope of this study. Khulusi (2000), differentiated between Arabicization and translation, considering Arabicization is merely transliterating a foreign term according to Arabic characters 'transliteration' or 'transcription', whereas he defined translation as transferring the meaning and the style from one language into another.

\section{The Concept of Arabicization}

The concept of Arabicization has been developed through time and it has acquired many other connotations. These developments have given Arabic language the strength to find equivalent words to the foreign lexeme counterparts that help to enrich the Arabic language with a wide range of lexical elements. For this reason, Arabicization makes Arabic a living language and highly comprehensive covering all aspects of life.

Well into the past, Arabs had dealt with the concept of Arabicization, with many Arab grammarians referring in their works to arabicized, loan and borrowed words from other languages. However, the concept of Arabicization is controversial, and a number of studies have investigated it. Al-Magraby (1908), for example, considered Arabicization as a natural transformation and development of gradual change that occurs in the language, and as such follows its general characteristics. Thus, arabicizing foreign terms constitutes a continuing movement within it. Nusayr (1982:115-116) discussed the process of Arabicization indicating to two principles that must be followed when arabicizing a new term: firstly, the arabicized word must fit the structural molds "qawalib" and patterns "awzãn" of Arabic language. Secondly, the meaning and the referent of the word (the original word) must be agreed upon by more than one of the universal languages such as English, French or German.

In this study, the researchers do not deal with other meanings of Arabicization from the side of generalization of the use of Arabic language in education. The concept of Arabicization here is restricted to the linguistic use of foreign words into Arabic language after they have been adjusted phonologically, morphologically and syntactically. That means when a foreign word is arabicized, it implies that the word is borrowed from another language and used in Arabic without modifications "borrowed words" or with some modifications or filtration "Arabicized words". In other words, the term "Arabicization" is used here referring to the process of 
transliterating a foreign word according to the Arabic phonological, morphological and syntactic rules.

\section{The Linguistic Importance of Arabicization}

The linguistic importance of Arabicization is represented in two phases. The first phase is that Arabicization develops and enriches the Arabic language through receiving an influx of new foreign words which are adjusted to the rules of the Arabic language and later exposed to the

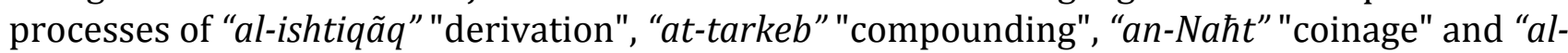
qiyãs" "analogy". The rush of new foreign terms into the Arabic language within a short period forces the Arabic speakers to use the foreign term before the specialists compose its Arabic equivalent. Moreover, even if the equivalent Arabic term is introduced, people will find it strange initially and refrain from using it. For instance, the word "internet" was arabicized as "alshabakah alankabutia" "webnet" or "alshabikah" "networker". Although the word has a clear connotation, it is not used by the general people because they have become familiar with the foreign word and find it difficult to replace that strange arabicized term. This is called 'Lexical Arabicization', which is also out of the scope of this study. However, with redoubled efforts, especially through the media, arabicized words can spread widely. For example, in Kuwait, people used to use the word "kindation" for the English word "air-condition", but now due to its extensive use in the media, the word has completely disappeared and has been replaced by the arabicized word $>$ mukayif.

The second phase, Arabicization encourages comparative linguistic studies. It leads to the revival of some Arabic terms (classical Arabic). There is an abundant empirical data to suggest that many foreign words, which are adjusted to the Arabic morphological rules are found to be, in fact, original Arabic words. The best example is the word "Algeba".

\section{Methods of Modifications in Arabicized Words}

Sibawayeh (1983) is one of the first Arab grammarians who tabulated the methodology adopted by Arabs in Arabicization. Although his confession that the Arabs have borrowed some terms from other languages which have not been exposed to any morphological modifications, he pointed out the morphological modifications such as substitutions, diacritics, and deletions that occurred to arabicized words when they were adjusted to effect a concord with the Arabic morphological patterns. Abu Hayan (1998) classified foreign words into three types: 1) words which were modified by the Arabs and became a part of their language. These words follow the Arabic morphological pattern, therefore, they are treated the same as their Arabic origin counterparts e.g. > dirhim "coin" < darhim; 2) words that entered the Arabic language and exposed to some slight phonological modifications to agree with Arabic pronunciation, but not affected morphologically e.g > muhandis "an engineer" < muhandiz; and 3) words that are not affected by any kind of modifications "borrowed or loan words" e.g. > tilifon "telephone" < telephone; > tilifizyon "television" < television; > computer "computer" < computer, etc.

\section{Types of Arabicized Words}

Arabic language is characterized from other languages by a special linear sequential arrangements of morphemes identified as "morphotactics". This makes it easy to determine the Arabic word from the foreign one. Arab grammarians such as (Ibn Jini: 1951), Abu Hayan (1998) and others indicate five constraints through which the reader can easily notice whether the word is from Arabic origin or arabicized word. These constraints are: 1) when the word does not follow the Arabic morphological patterns /fã/, /'ain/, /lãm/."fa-a-la" such as > Gabriel, > Khorasan, > Abraham, etc.; 2) if the /fã / is /nŭn/, the /'ain/ is /rã/, that is the /rãa and the 
/nŭn/ come in consecutive order e.g. > narjis "narcissus"; 3) if the word ends with /dãl/ and /zãi/ in consecutive order e.g. the Persian word < muhandiz "an engineer"; 4) words consist of /gĩm/ and /sãd/ like > sanj "dulcimer", > solajan "scepter" etc.; and words contain /gĩm/ and /qãf/ such as > manjaniq "catapult", > joga "chorus", etc.; and 5) four/five-letter words that do not contain what is called "zalaqa letters", /rã/, /lãm, /nŭn/, /fãa/, /bãa/, and /mĩm/ such as > josag "small palace". Another classification to recognize arabicized words, Arab linguists graded their types into four parts:

1) Words which have no change in forms and are not found in Arabic e.g., > Khurasan "country name" < Khurasan.

2) Words which have no change in form but adjusted to the Arabic pattern e.g., > khurrum "soft life" which is analogized with /summul/ "determined".

3) Words which have a change in the form but are not found in Arabic e.g., > ãjir "clay" < ãjir.

4) Words which have a change in the form and analogized with equivalents in Arabic language e.g. > dirhim "a currency" which is analogized with the Arabic word /hijri/, which is balanced morphologically with "filil" < darhim.

\section{The Morphological Pattern of Arabicized Words}

The Arabic language has a surface pattern "maizan sarfy" or "wãzin" consisted of three letters /fã/, /'ain/ and /lãm/ "fa-a-la" "فعل". This word pattern permits to detect the letters of the root of any foreign word. For example, the pattern of "yalabŭn", "playing" is "yafalŭn" "doing", the letters /fã/, /'ain/ and /lãm/ replace the letters of the root of "yalabŭn", and the pattern of "qãl" "said" is "fa'al" "did". Therefore, any arabicized word must follow one of these forms as shown in Table 1.

\begin{tabular}{|c|c|}
\hline $\begin{array}{l}\text { Arabic Morphological } \\
\text { Pattern " } f a-a-l a \text { " (Balance) }\end{array}$ & Examples of Arabicized Words \\
\hline faieel & $>$ fanieez or $>$ banieed "a kind of sweet" \\
\hline إفيعلل Ifilil & > Ibrism "silk" \\
\hline falil فاعليل & $>$ narjil "coconut" \\
\hline fülil فُعليل & $>$ zŭrvin "a group of people or a doorknob" \\
\hline أفحُل afül & $>$ ajjir "clay or mud" \\
\hline faül فُعُل & $>$ ãnŭk "white zinc" \\
\hline فعلًل & $>$ karkadan "an animal" \\
\hline füalal فُعالل & > süradiq "a fence" \\
\hline فِعلل filal & $>$ nirjis "a kind of flowers" \\
\hline füalan فُعالان & > Khurasan "a place" \\
\hline فعلول falŭl & $>$ tambŭr "musical instrument" \\
\hline afãal أفعال & > ãrad "a kind of dates" \\
\hline فعَل & $>$ baqqam "a kind of trees" \\
\hline فعلَّ falal & > shataranj "chess" \\
\hline فُعلل fülul & > kŭrkŭm "a kind of plant" \\
\hline fi'il فِعِ & $>$ frind or $>$ brind "a sword" \\
\hline فاعول faül & $>$ hanŭt "wine, bar" \\
\hline فعليل falil & > qünbit "beans" \\
\hline müfalala مُفعللة & $>$ mushakhbala "wears jewelry and beards" \\
\hline
\end{tabular}

Table1. The Morphological Pattern of Arabicized Words 
To establish agreement with the Arabic morphological pattern "mizan sarfi","fa-a-la", the Arabic language also uses "al-qyãs" "analogy" in arabicizing words. For example, words like $<$ dirhim, "currency" is attached to the Arabic word "hijri" "the fool", in the surface pattern of "fi'lil" which is a common pattern in Arabic. The word < bahraj, "unreal" is attached to "salhab", "the tall" in the surface pattern of "fa'lal". The word < Isa'aq, is attached to "ibham", "finger" in the surface pattern of "ifãl". The word < jorab, "leather socks" is attached to "kawkab" "a star" in the surface pattern of "fa'lal"; and < yaqŭb, "a kind of birds" was attached to "yarbŭ" "a kind of rats" in the surface pattern of "falǔl".

\section{How are Arabicized Words Modified?}

When foreign words are arabicized, there is always a necessity to change their structures. The modifications usually occur in three forms, which will be discussed in more detail: 1) replacing a letter for a letter (alteration); 2) adding or deleting a letter; and 3) changing the diacritics.

\subsection{Replacing a letter for a letter (Alteration):}

Replacing letters in arabicized words always occurs due to the difference in the sequential arrangements of some letters in foreign words with the concatenation of Arabic language. There are ten letters that can be replaced in arabicized words. Five of them can be regularly

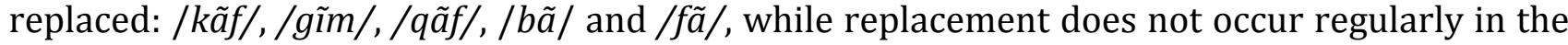
other five letters: /sĩn/, /shĩn/, /ain/, /lãm/ and /zãi/. An example for regular replacement in Persian words like < kŭrbŭz, "a small shop", which is arabicized into > qŭrbŭq where the /kãf/ is replaced by /qũf/. The sound is between the /kãf/and /gĩm/. Then, the /gĩm/is replaced by $/ q \tilde{a} f /$ for the same reason. The same action occurs in the Persian word < korab "socks", which is arabicized into > jorab. Examples for irregular replacement occurs in the words like < Ishmael, which is arabicized as > Ismã îl, where the /shĩn/ is as commonly replaced by /sinn/ and /hamza/ by /'ain/; and the Persian word < dashit, "the desert" which is arabicized into > dist, where the /shĩn/is replaced with /sĩn/.

In addition, the replacement of letters in arabicized words occurs due to a similarity in articulation. Replacement of letters in Arabicized words always occurs when unfamiliar letters enter the Arabic language. This usually happens with words that have a similarity in the way they are articulated. Examples for that are found in Persian words like $<$ likam, and $<$ bank, which have sounds between /kãf/ and /gĩm/, arabicized into > lijam "a robe for tying animals" and > banj "a plant used for anesthesia". Sometimes the /kãf/ is replaced by /qũf/ such as < kurbuz "a small shop" which is changed into $>$ qurbŭj. In addition, the consonant letter $/ h \tilde{a} /$ is replaced by /gĩm/ as in the Persian words < kosa, "a person who has short teeth", < moza, "leather socks" and < banafsha, "a color" to be arabicized as > kosaj, > mozaj and > banafsaj respectively. For the same reason, the /shĩn/ is replaced by /sin/ as in the Persian word < sharawil, or < ishmawil, "long pants" which is arabicized into $>$ sarawil and $>$ ishmawil. Table 2 below shows replacement of letters that occurs to arabicized words due to the similarity in articulation. 


\begin{tabular}{|c|c|c|c|}
\hline Foreign Word & Origin & $\begin{array}{l}\text { Arabicized } \\
\text { Word }\end{array}$ & Replacement \\
\hline$<$ dashit "the desert" & Persian & $>$ dast & The /shĩn/is replaced by /sĩn/ \\
\hline $\begin{array}{l}<\text { likam or ligham "a robe } \\
\text { for tying animals" }\end{array}$ & Persian & > lijam & $\begin{array}{l}\text { A letter sounds between the letters / } k \tilde{a} f / \text { and } \\
\text { /gĩm/ }\end{array}$ \\
\hline$<$ kinda "trench" & Persian & $>$ khandaq & 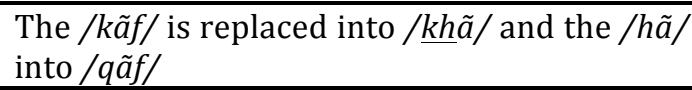 \\
\hline < aldiabãn "guard" & Persian & $>$ aldidabãn & The letter /zãl/is replaced by /dãl/ \\
\hline$<$ zarkun "wine" & Persian & $>$ alzarjun/ & The letter / $k \tilde{a} f /$ is replaced by /gĩm/ \\
\hline < birnid "the sword" & Persian & $>$ firnid & 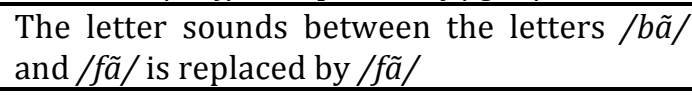 \\
\hline $\begin{array}{l}\text { < shamuel "a gift from } \\
\text { Allah" }\end{array}$ & Persian & $>$ alsamawal & The letter /shĩn/is replaced by /sinn/ \\
\hline < shirwal "pants" & Persian & $>$ sirwal & The letter /shĩn/is replaced by /sinn/ \\
\hline$<$ Ishmael "person name" & Biblical Name & $>$ Ismã $\tilde{l} l$ & The letter /shĩn/is replaced by /sinn/ \\
\hline $\begin{array}{l}<\text { barnasha "a human } \\
\text { being" }\end{array}$ & $\begin{array}{l}\text { Nabataea- } \\
\text { Serilean- Roman }\end{array}$ & > barnasa & The letter /shĩn/is replaced by /sinn/ \\
\hline $\begin{array}{l}<\text { kawashak "the sword's } \\
\text { cover" }\end{array}$ & Nabataea & $>$ josag & 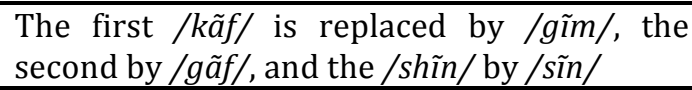 \\
\hline $\begin{array}{l}<\text { khurba or khawraba "an } \\
\text { animal" }\end{array}$ & Persian & $>$ alhirba & The letter / $\underline{k h} \tilde{a} /$ is replaced by $/ h \tilde{a} /$ \\
\hline$<$ kulshan "white flower" & Persian & $>$ Julsan & $\begin{array}{l}\text { The /kãf/is replaced by /gĩm/and the /shĩn/ } \\
\text { by /sinn/ }\end{array}$ \\
\hline$<$ korab "the sandal" & Persian & $>$ jorab & 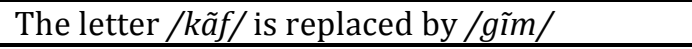 \\
\hline$<$ Moses "a person name" & Biblical Name & $>M \breve{s} s \tilde{a}$ & The letter /shĩn/is replaced by /sĩn/ \\
\hline $\begin{array}{l}\text { kurbuk or kurbuj "a } \\
\text { store" }\end{array}$ & Persian & $>$ qurbuq & $\begin{array}{l}\text { The letters /kãf/ or /gĩm/ are replaced by } \\
/ q \tilde{a} f /\end{array}$ \\
\hline$<$ karra "a mug" & Persian & > jurra & 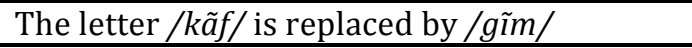 \\
\hline $\begin{array}{l}<\text { kawhar "a precious } \\
\text { stone" }\end{array}$ & Persian & $>$ jawhar & The letter / $k \tilde{a} f /$ is replaced by /gĩm/ \\
\hline$<$ tashit "basin" & Persian & $>$ tast & The letter /shĩn/is replaced by /sinn/ \\
\hline < kahrman "a red color" & Persian & > gahrman & The letter / $k \tilde{a} f /$ is replaced by /gĩm/ \\
\hline < shukar "sugar" & Persian & > sukar & The letter /shĩn/is replaced by /sĩn/ \\
\hline $\begin{array}{l}<\text { bazinkan "a kind of } \\
\text { plant" }\end{array}$ & Persian & $>$ bazinjan & The letter / $k \tilde{a} f /$ is replaced by /gĩm/ \\
\hline$<$ lashkar "soldiers" & Persian & $>$ alaskar & The letter /shĩn/is replaced by /sinn/ \\
\hline$<$ kurshun "cotton" & Persian & $>$ kursun & The letter /shĩn/is replaced by /sinn/ \\
\hline $\begin{array}{l}<\text { dahkan "the strong } \\
\text { person" }\end{array}$ & Persian & $>$ dahgan & The letter /kãf/is replaced by /gĩm/ \\
\hline$<$ jirag "light" & Persian & $>$ siraj & $\begin{array}{l}\text { The letter /gĩm/is replaced by /sĩn/, and the } \\
\text { /ghain/is replaced by /gĩm/ }\end{array}$ \\
\hline$<$ akor "a kind of mud" & Persian & $>$ ajur & 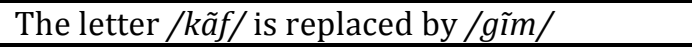 \\
\hline$<$ kirda "bagel" & Persian & $>$ jirdig & $\begin{array}{l}\text { The letter / } k \tilde{a} f / \text { is replaced by /gĩm/, and the } \\
/ h \tilde{a} / \text { is /qãf/ }\end{array}$ \\
\hline$<d u b a j$ "silk garment" & Persian & $>$ dibaj & The letter /qũf/is replaced by /gĩm/ \\
\hline$<$ muhandiz "an engineer" & Persian & $>$ muhandis & The letter /zãi/ is replaced by /sĩn/ \\
\hline < sark "saddle" & Persian & $>\operatorname{sarj}$ & The letter / kãf/is replaced by /gĩm/ \\
\hline$<$ alzijinjil "the mirror" & Roman & $>$ alsijinjil & The letter /zãi / is replaced by /sĩn/ \\
\hline $\begin{array}{l}<\text { alarban or alarbun } \\
\text { "earnest, retainer" }\end{array}$ & Persian & $>$ alarbun & The /hamza/ is replaced by 'ain/ \\
\hline < zindik"libertine" & Persian & $>$ zindiq & The letter / $k \tilde{a} f /$ is replaced by /qũf/ \\
\hline
\end{tabular}

Table 2. The Modifications due to Replacement of Letters (Alternation) 


\subsection{Addition and Deletion of Letters}

In some other cases, some words are arabicized by adding and deleting of letters. This process always goes concurrently in the same word i.e. sometimes it is necessary to add and delete some letters. The Roman word < firdasã "the palace" is arabicized into > firdos by adding the letter /wãw/, the Persian word < zũbaq < "troublesome" is arabicized into > zũbaq by adding the /tã marbũta/. The Persian words < sãh dīr "the palace" is arabicized into > sadir by deleting

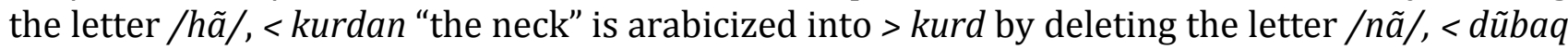
"the silk" is arabicized into > dibaj by deleting the letter /wãw/. Table 3 below shows the modifications that occurred to some arabicized words due to adding a letter.

\begin{tabular}{|c|c|c|c|}
\hline Foreign Word & Origin & $\begin{array}{l}\text { Arabicized } \\
\text { Word }\end{array}$ & Modifications \\
\hline $\begin{array}{l}< \\
\text { "bar" }\end{array}$ & Persian & $>$ khornaq & 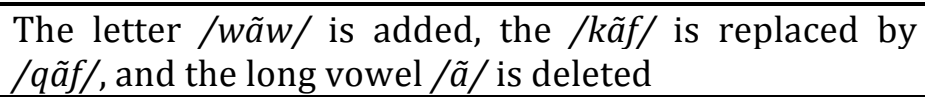 \\
\hline $\begin{array}{l}<\text { dinnãr } \\
\text { "currency" }\end{array}$ & Persian & $>\operatorname{din} \tilde{a} r$ & The /shadda/is deleted, and the /yã / is added. \\
\hline < jokãn "sceptre" & Persian & $>$ şolajãna & $\begin{array}{l}\text { The letter /jim/ is replaced by added /șãd/, the letter } \\
/ k \tilde{a} f / \text { is replaced by } / j i m / \text { and } / h \tilde{a} / \text { added. }\end{array}$ \\
\hline$<$ barzan "mule" & Persian & > birzon & $\begin{array}{l}\text { The first /alif/ is deleted, and the second is replaced to } \\
/ w a \tilde{a} w /\end{array}$ \\
\hline < ãston "cylinder" & Persian & $>^{\circ}$ stwanã & $\begin{array}{l}\text { The long vowel / } \tilde{a} / \text { is replaced by /hamza/, the letter } \\
/ \sin / \text { is replaced by /sãd/, and /tã marbuta/is added. }\end{array}$ \\
\hline $\begin{array}{l}<\text { abash "a group } \\
\text { of people" }\end{array}$ & Persian & $>$ awbash & The letter / wã $w /$ is added. \\
\hline$<$ ziwah "mineral" & Persian & $>$ zibaq & 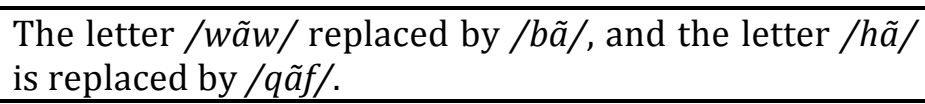 \\
\hline $\begin{array}{l}<\text { damsa "white } \\
\text { silk" }\end{array}$ & Persian & $>$ damaqs & 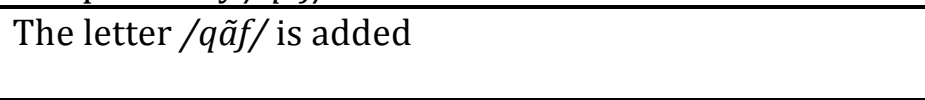 \\
\hline
\end{tabular}

Table 3. The Modifications due to Adding a Letter or Letters

However, Table 4 below shows the modifications occurred to arabicized words due to deleting a letter or letters.

\begin{tabular}{|c|c|c|c|}
\hline Foreign Word & Origin & $\begin{array}{l}\text { Arabicized } \\
\text { Word }\end{array}$ & Replacement \\
\hline $\begin{array}{l}<\text { boystan "a name of a } \\
\text { place" }\end{array}$ & Persian & $>$ bustan & 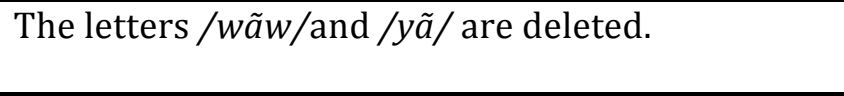 \\
\hline$<$ albisk"the cat" & Persian & $>$ albas & The letter / $k a \tilde{f} /$ / is deleted \\
\hline < sunck-wa-kil "clay" & Persian & $>$ sijeel & $\begin{array}{l}\text { The letters } / n u ̆ n /, / k \tilde{a} f / \text { and } / w \tilde{a} w / \text { are deleted and } \\
\text { replaced by } / \text { jim/, and } / y \tilde{a} / \text { is added. }\end{array}$ \\
\hline $\begin{array}{l}\text { saradãr } \\
\text { "underground path" }\end{array}$ & Persian & $>$ surdaq & $\begin{array}{l}\text { The last long vowel } / \tilde{a} / \text { and } / r \tilde{a} / \text { are deleted and } \\
\text { replaced by /qũf/ }\end{array}$ \\
\hline $\begin{array}{l}<\text { shãhan-shah "great } \\
\text { king" }\end{array}$ & Persian & > shahnshah & The short vowel / $a$ / is deleted \\
\hline
\end{tabular}

Table 4. The Modifications due to Deleting a Letter or Letters

\subsection{Change in the diacritics}

In some arabicized words, one or more letters was/were added to indicate a special phonetic value. That means the structure of foreign words was changed to cope with the Arabic phonological pattern. In Arabic language, this always happens through the diacritics. The Arabic script has many diacritics such as the "i'jam" "consonant pointing" and "tashkĩl" 
"supplementary diacritics" which includes the "harakat" "vowel marks". When any change happens in letters, it is usually followed by changes in the diacritics. An example for this comes from the Persian word < kafjalaz, "ladle" which is arabicized as > qafshalīl, where the letters /kãf/ and /jĩm/ are replaced by /qũf/ and /shĩn/ respectively; and the /fathã/ on the /lam/is replaced by /kasrã /, and the /alif/ is replaced by the long kasrã /ī/. The replacement occurs in both the letter and in the diacritics (Al-Jawaliqi, 1998: 7).

\section{Modification: Morphological, Syntactic or Morpho-syntactic?}

Classical Arabic has a tight and cohesive system where everything runs in a certain order. All phonemes and morphemes are in a concatenating order. For this reason, any foreign word that enters the Arabic language must be adjusted to its morphological and phonological rules. In order to illustrate whether the kinds of modification in arabicized words happen morphologically, syntactically, or morpho-syntactically, one has to explain the morphology and the syntax of the Arabic language. Morphology is concerned with the structure or forms of words primarily through how morphemes are constructed. It deals with the changes that happen to words such as addition or deletion of suffixes. However, syntax deals with the rules governing the combination of words in sentences. It is concerned with the case of the word whether it is nominative, accusative or genitive.

Most of the modifications that occurred to arabicized words are morphological. After the adjustment, which occurred to the arabicized word in order to be adopted to the Arabic morphological and phonological patterns, it is put in a sentence to be used for daily speech, which is part of syntax. Then, the Arabicized word is adjusted phonologically according to its position in a sentence by adding some diacritics. In the Arabic language, however, some words cannot subjected to diacritics for different reasons. For example, proper names are not diacriticized for two reasons: proper and foreign names such as /Ibrãhĩm/. Table 5 below shows some examples for the modifications occurred to the arabicized word and whether these changes are morphological, syntactical or morpho-syntactic. 


\begin{tabular}{|c|c|c|c|}
\hline Foreign Word & Arabized Word & Modifications & $\begin{array}{l}\text { Kind of } \\
\text { Change }\end{array}$ \\
\hline $\begin{array}{l}<\text { kharinkah or }<\text { khorinkah } \\
\text { "dining room" }\end{array}$ & >alkhornaq & $\begin{array}{l}\text { A change in the main structure and addition } \\
\text { of the Arabic definite article /al/ }\end{array}$ & Morphological \\
\hline < sah-dal "palace" & $>$ alsadir & $\begin{array}{l}\text { A change in the main structure and addition } \\
\text { of the Arabic definite article /al/ }\end{array}$ & Morphological \\
\hline $\begin{array}{l}<\text { dunbah- < barah "a } \\
\text { musical instrument" }\end{array}$ & $>$ altanbur & $\begin{array}{l}\text { A change in the main structure and addition } \\
\text { of the Arabic definite article /al/ }\end{array}$ & Morphological \\
\hline$<$ barnamah "program" & > barnãmij & A change in the main structure & Morphological \\
\hline$<$ banafshah "violet" & > banafsaj & A change in the main structure & Morphological \\
\hline < kahnnam "hell" & > Jahannam & A change in the main structure & Morphological \\
\hline $\begin{array}{l}<\text { hawareyon "Jesus's } \\
\text { followers" }\end{array}$ & > hawareyon & A change in the main structure & Morphological \\
\hline zarjun " wine" & > Almuzarij & $\begin{array}{l}\text { derived word and addition of the Arabic } \\
\text { definite article /al/ }\end{array}$ & Morphological \\
\hline < dirhim "currency" & $\begin{array}{l}>\text { darham or } \\
\text { mudarhim }\end{array}$ & Words derived & Morphological \\
\hline < duibaq "silk garment" & $>$ aldibaj & $\begin{array}{l}\text { A change in the main structure and addition } \\
\text { of the Arabic definite article / al/ }\end{array}$ & Morphological \\
\hline $\begin{array}{l}<\text { sahrir or < shahrir " a } \\
\text { kind of dates" }\end{array}$ & $\begin{array}{l}>\quad \text { alsihrir or } \\
\text { alshahrir }\end{array}$ & The addition of the Arabic definite article /al/ & Morphological \\
\hline < firdasah "paradise" & $>$ alfirdos & $\begin{array}{l}\text { A change in the main structure and addition } \\
\text { of the Arabic definite article /al/ }\end{array}$ & Morphological \\
\hline$<$ bostan "garden" & $>$ albustan & $\begin{array}{l}\text { A change in the main structure and addition } \\
\text { of the Arabic definite article / al/ }\end{array}$ & Morphological \\
\hline $\begin{array}{l}<\quad \text { sunck wackal "the } \\
\text { mirror" }\end{array}$ & > alsijinjil & $\begin{array}{l}\text { A change in the main structure and addition } \\
\text { of the Arabic definite article / al/ }\end{array}$ & Morphological \\
\hline < kawjak"the slim" & $>$ gosh & $\begin{array}{l}\text { A change in the main structure and addition } \\
\text { of the Arabic definite article / al/ }\end{array}$ & Morphological \\
\hline <muq "sandal" & $>$ alkhuf & $\begin{array}{l}\text { A change in the main structure and addition } \\
\text { of the Arabic definite article / al/ }\end{array}$ & Morphological \\
\hline$<$ nabharah "unreal" & $>$ bahraj & $\begin{array}{l}\text { A change in the main structure and addition } \\
\text { of the Arabic definite article /al/ }\end{array}$ & Morphological \\
\hline $\begin{array}{l}\text { < kardan or qardan "the } \\
\text { neck" }\end{array}$ & $>$ alkard & $\begin{array}{l}\text { A change in the main structure and addition } \\
\text { of the Arabic definite article /al/ }\end{array}$ & Morphological \\
\hline $\begin{array}{l}\text { < ramah or ramak "last } \\
\text { breath" }\end{array}$ & $>$ alramaq & $\begin{array}{l}\text { A change in the main structure and addition } \\
\text { of the Arabic definite article / al/ }\end{array}$ & Morphological \\
\hline $\begin{array}{l}<\quad \text { baradah "hostage } \\
\text { women" }\end{array}$ & $>$ albardaj & $\begin{array}{l}\text { A change in the main structure and addition } \\
\text { of the Arabic definite article / al/ }\end{array}$ & Morphological \\
\hline
\end{tabular}

Table 5. Modifications: Morphological, Syntactic or Morpho-syntactic

From Table 5 above, it is noticed that most words show that the modifications occurred in arabicized words are morphological changes.

\section{Can Arabicized Words be Derived?}

Concerning derivation, Arabic grammarians classify the arabicized and loan words into two types: proper nouns and words treated as proper nouns.

\subsection{Proper nouns:}

Proper nouns are nouns which do not end in /alif/ "maqsũr" such as Salma, or end in /hamza/ "mamdũd" such as hamrã, or end in /ya/ "manqũs" e.g., al-qadi. Therefore, words like > alfirind 
"the sword", > almozaj "the leather socks", > alistabraq "the silk" and > albaziq "the wine" are proper nouns. Arabicized proper nouns are dealt in the same as their Arabic counterparts that is they cannot be derived though there are some exceptions. However, they can be pluralized or made small. Even if there is a complete agreement between a foreign word and an Arabic word, it does not mean that one word is derived from another. For example, the name of the prophet/Ishãq/, is not derived from the verb "ashaqahũ" "demolish" in this phrase "ashaqahũ Allah ishaqan" "demolished completely by God" and the other derivations of this word such as the phrases "thobe sahīq" "a torn out thobe", "nakhlatun sahŭq" "a tall palm tree", /sahŭq/ "a name of a place" and "makãn saheeq" "deep place". Another example is the Biblical name < Ya'qŭb/ is not driven from "alya'qŭb" "the eagle". (As-Sũti (1958: 288-290); Al-Jawaliqi (1998: 8-9); Addi Shair, (1908: 62, 77.)

\subsection{Words treated as proper nouns:}

Words treated as proper nouns in their source language and in the Arabic language but adjusted phonologically to cope with the Arabic lexical terms. These words are not subjected to diacritics in Arabic language e.g. the Biblical names "Ibrãhĩm", "Ishãq", "Ya'gŭb" etc., and nonArabic country names like "Samarqand" "a city in Uzbekistan", "Khorasan" "a Persian city". Therefore, such words are accepted into the lexicon of literary Arabic and fully assimilated morphologically. They were subjected to all rules of Arabic words including derivation but not diacriticization. For instance, the word > lijam is arabicized from the Persian word < likam, which is pluralized as > lŭjŭm just like their saying "kitab - kŭtŭb" "book - books". The Arabs have also derived from it the imperative verb "aljimhü", the past verb "aljamahũ", the gerund "iljãm", the agent "mŭljim", and the objective "mŭljam". Other examples include "mŭzarjan" from "alzarjŭn" "the wine", and "mŭqamjar" "the archer -who makes arches" from "qamjar". The arabicized noun > dĩbãj "silk brocade" is from the Persian word < dĩbãq. Besides, the Arabs have also derived from it the verb "dabbaja" "to embellish" and the adjective "mudabbajat" "figures of speech". The Arabs have also derived from the Persian word < dawwan, "devel writers", the verb > dawwan "write" and the noun > daiwan "a book of poetry", which is pluralized as /dawaween/. They have also formed verbs like > sajjala "to register" from < sijil; > twarrada "to become rose colored" from < ward. From the Nabitean word "hĩrzoga" "trap", the word "mŭharzag" "trapped" is derived. From the broken plurals such as the Greek word < philsophia they have formed > falãsifa "philosophers" and > jawahĩr "jewels" from < jawahara, and $>$ wurŭd "roses" from < warda etc. Table 6 below shows more examples of nouns that have been derived and the kind of derivation. 


\begin{tabular}{|c|c|c|c|}
\hline Foreign Word & $\begin{array}{l}\text { Arabized } \\
\text { Word }\end{array}$ & Derivation & $\begin{array}{ll}\text { Kind } & \text { of } \\
\text { Derivation }\end{array}$ \\
\hline$<$ manjaneeq "cannon" & $\begin{array}{l}> \\
\text { almanjaneeq }\end{array}$ & $\begin{array}{l}>\text { nãjiq "a person who shoots } \\
\text { with almanjaneeq" }\end{array}$ & Participle \\
\hline$<$ mãh rũz "histroian" & $>$ almũarrikh & $\begin{array}{l}\text { > arrakha } \\
>\text { yurrikh } \\
>\text { tarikh }\end{array}$ & $\begin{array}{l}\text { Past simple } \\
\text { Present simple } \\
\text { Gerund }\end{array}$ \\
\hline$<m a h r$ "ring" & $>a l m a h r$ & $>$ mamhũr & Accusative \\
\hline < zindah-kird "iternity" & $>$ zindeeq & $\begin{array}{l}\text { > zandaqa } \\
>\text { tazandaqa }\end{array}$ & $\begin{array}{l}\text { Gerund } \\
\text { Past simple }\end{array}$ \\
\hline < dahkhan "chief" & $>$ dihqan & $\begin{array}{l}>\text { tadahqan } \\
>\text { dahqanatun }\end{array}$ & $\begin{array}{l}\text { Present simple } \\
\text { Gerund }\end{array}$ \\
\hline <sãruj "mud" & $>$ Alsihreej & $\begin{array}{l}\text { > sahraja } \\
\text { > sarraja } \\
\text { > musahraj }\end{array}$ & $\begin{array}{l}\text { Past Simple } \\
\text { Past Simple } \\
\text { Accusative }\end{array}$ \\
\hline$<$ biteerah "penguin" & $>$ albatreeq & $>$ tabatraqa & Past Simple \\
\hline $\begin{array}{l}<\text { noruz "the first day of the } \\
\text { year" }\end{array}$ & $>$ alnairŭz & $\begin{array}{l}\text { > nawraza } \\
>\text { minawriz } \\
>\text { minairiz }\end{array}$ & $\begin{array}{l}\text { Past Simple } \\
\text { Participle } \\
\text { Participle } \\
\end{array}$ \\
\hline $\begin{array}{l}<\text { shon boz (keif) "floating } \\
\text { wood for crossing rivers" }\end{array}$ & $>\operatorname{shunbuz}$ & $>$ mushanbiz & Participle \\
\hline $\begin{array}{l}<\underset{\text { dirham }}{<\text { or dirim }} \text { "a } \\
\text { currency" }\end{array}$ & $>$ dirhim & $\begin{array}{l}>\text { mudarhim } \\
>\text { mudarham }\end{array}$ & $\begin{array}{l}\text { Participle } \\
\text { Accusative }\end{array}$ \\
\hline
\end{tabular}

\section{Table 6. The Kinds of Derivation}

\section{Conclusion}

a. Arabicization is a morphological rather than a syntactic phenomenon because the modifications and the adjustments that occurred in the structure and the form of the arabicized word and the applications of syntactic rules happened after the adjustment of the arabicized word.

b. The non-Arabic words used by Arabs which are not adjusted phonologically and morphologically are considered as loan words, not arabicized words.

c. The Persian literary and material culture left an influential mark on the lexicon of Arabic.

d. Arabicization is an evidence for the interactions and integrations of languages rather than a language policy in itself.

e. The acceptance of foreign words in Arabic language does not mean that it is a weak language, but it is an evidence of its power and its ability for inclusion. Although some believe that Arabic has a rigid linguistic system that does not accept foreign words as they are. There is a process of adjustments in arabicization even if the new item can smoothly go into the stream of Arabic, not like other languages such as English, which takes in from all languages with no change.

\section{Work Cited}

Adi Sheir Alkaldani. (1908). Mujam alalfaz Alfarisya Almurraba. Beirut.

Al-Atram, M. A. (1990). Effectiveness of natural language and indexing in retrieving Arabic documents [in Arabic]. King Abdulaziz City for Science and Technology. Project number AR-8-47. Riyadh. Saudi Arabia. 
Al-Fayumi, Ar-Rafi. (1993). Al-Misbah Al-Munir. (Verified by Ahmed Abdulgafour Attar). Lebanon, Bairut: Dar Alkutub. $1^{\text {st }}$ ed.

Al-Jawahri. (1978). As-sahãh, Dar Alilm lilmalaeen, Beirut, 2nd ed. Pp.179.

Al-Jawaliqi, Abu Mansour. (1998). Almurrab min Alkalam Alajami ala Hirouf Almijam. Dar Algalam. Damascus. $1^{\text {st }}$ ed.

Al-Khafaji, Shihabadin.(1998). Shifa Alqalil fima fi Kalam alarab min aldakheel. Lebanon, Beirut: Dar Alkutub Alilmeyah, $1^{\text {st }}$ ed.

Al-Magraby (1908).

Al-Tha'albi, Abu Mansour. (1038). Fiqih Al-Luqa wa Sir Alarabiya. Lebanon, Beirut: Dar Al-Hayat Library. $198-199$.

Al-Zubaidi (1966). Taj Al-Arŭs. Lebanon, Beirut: Dar Sadir. 8,226.

As-Sŭti, Jalaledin. (1906). Al-Mazhar fi Ulum Al-Luqa wa Anwaihã. (Verified by Mohammed Ahmed Jadalmula and others). Cairo: Dar Alturath Library. $3^{\text {rd }}$ ed.

As-Sŭti, Jalaledin. (1958). Al-Muhazab fima waqa fi Al-Qu'ran Alkarim min Almurrab. (Commentary by Mohammed Ahmed Jad Al-Mawla. (in Arabic). Cairo: Al-Babi Al-Halabi Printing Press. $1^{\text {st }}$ ed.

Ghoniem, Karim. (1989). Arabic Language and Targeted Scientific Renaissance. (in Arabic) Alem Al-Fikir 19.4 37 80 .

Abu Hayyan Al-Andalusi. (1998). Al-Bahr Al-Muheet. (Verified by Sidqi Mohammed Jameel). Lebanon, Bairut: Dar Al-Fikr.

Ibn Jínní, Abu Al-Fath Osman. (1951: 358). Al-khasais "Characteristics" $1^{\text {st }}$ ed.

Khulusi, Safaa. (2000). The Art of Translation (in Arabic). $2^{\text {nd }}$ ed. Cairo: The Egyptian Public Commision. Print.

Nusayr, Abdel Majeed. (1982). The Arabicization of the University Education: Natural Science. (in Arabic). Paper presented. Conference of Arabicization. Damascus. 27 Apr. - 3 Ma. Print. 115-116.

Sayadi, Mohammed. (1985). Arabicization and Its Coordination in the Arab World. (in Arabic). Beirut: Center of Arab Unity Studies. Print.

Sibawayeh, Amr bin Osman. (1983). Alkitab "the book". (verified by abdussalam Haroun). Alam Alkutub Print. $3^{\text {rd }}$ ed. 